\title{
MAXIMIZING CRITICALITY CONTROL COVERAGE FOR GEOLOGIC DISPOSAL OF DOE SNF
}

\author{
J. Wesley Davis \\ Framatome Cogema Fuels \\ 1211 Town Center Drive \\ Las Vegas, Nevada 89144
}

(702) $295-3818$

\begin{abstract}
Many types of Department of Energy (DOE) spent nuclear fuel (SNF) are being considered for geologic disposal. Maximizing the efficiency and effectiveness of the analyses for storage, transportation, and disposal is crucial to ultimately license for geologic disposal. A standardized canister has been designed to support interim storage, transportation, and ultimate disposal at the potential repository at Yucca Mountain. Disposal criticality analyses are being performed for fuel groups. The results from these analyses along with those from the storage and transportation criticality analyses, will be used to support acceptance of DOE SNF for disposal.
\end{abstract}

\section{INTRODUCTION}

The DOE spent nuclear fuel (DOE SNF) planned for disposal at the potential repository originated from domestic and foreign research reactors, U.S. reactors used for weapons production, and demonstration reactors. In addition, DOE has custody of some commercial spent fuel. The majority of the DOE SNF is stored at three sites: Hanford, Savannah River, and the Idaho National Environmental and Engineering Laboratory. The approximate quantity of spent fuel is 2,500 metric tonnes of heavy metal (MTHM). This spent fuel is being transferred from wet storage to dry storage in approximately 3,500 canisters. The National Spent Nuclear Fuel Program (NSNFP) coordinates among sites for the handling and storage of the DOE SNF.

\section{DISPOSAL CRITICALITY ANALYSES}

More than 250 types of DOE SNF are being considered for geologic disposal. Demonstrating that the probability and consequence of post-closure criticality are not significant in a geologic repository is important in the repository safety strategy, and ultimately, to the Nuclear Regulatory Commission (NRC). The NRC has proposed a new set of regulations to be issued as 10 CFR Part 63 (64 FR 8640) that will, if issued, apply to Yucca Mountain as a deep geologic repository. The methodology by which the risk associated with criticality will be evaluated has been documented in a topical report submitted to the $\mathrm{NRC}^{2}$ by the DOE Office of Civilian Radioactive Waste Management (OCRWM). This methodology, which is consistent with the draft regulation, is based on risk-informed analyses for application to all waste forms containing fissile material. This report defines the critical limits and provides examples of how the methodology can be applied to specific waste forms. The methodology includes the evaluation of potential intact through degraded configurations with supporting analyses of the physical and geochemical processes that might be experienced over time. One or more addenda to the topical report are planned to address the application to DOE SNF.

The methodology uses deterministic and probabilistic analyses to evaluate the various long-term degradation processes, the combination of events, and the consequences of any potential criticality. So that potential critical configurations can be developed, the methodology includes analyzing the geochemical and physical processes that can breach the waste package and degrade the waste forms. The riskinformed approach includes analyzing probabilities and consequences of criticality for those configurations that exceed the designated critical limit. If the acceptable probability threshold or consequence criterion is exceeded, then possible design changes will be investigated to reduce the probability and/or consequence of criticality. The criticality risk, which is the combination of the criticality probability and consequence for all configurations, is an input to 
the Total System PerformanceAssessment (TSPA), although DOE expects to show that the TSPA screening criteria will screen out criticality based on low probability and/or consequence.

\section{APPLICATION TO DOE-SNF}

The unique characteristics of the -250 types of DOE-SNF require unique designs for criticality control. As a result, the NSNFP and the Civilian Radioactive Waste Management System (CRWMS) Management and Operating Contractor (M\&O) have identified nine representative DOE SNF groups based on the driving factors for consideration in disposal criticality analyses'. These factors are fuel matrix, primary fissile isotope, geometry, and enrichment. The NSNFP has designated a representative fuel design within each fuel group for analysis as follows:

1. Mixed Oxide - FFTF driver assemblies

2. U-Mo/ U-Zr Alloys - Enrico Fermi derodded assemblies

3. High-Enriched U Oxide - ShippingportPWR assemblies

4. U-Zr-H - TRIGA-FLIP rods

5. U-233/Th oxide - Shippingport-LWBR Assemblies

6. U-Al -Melt \& Dilute waste form

7. Low-Enriched U metal - N-Reactor assemblies

8. U carbide - Ft. St. Vrain

9. Low-Enriched U oxide - TMI fuel debris.

An 18-inch-diameter standardized SNF canister shell design has been developed by the NSNPF for storage, transportation, and disposal ${ }^{3}$ of DOE SNF. The conceptual internal basket designs for the fuel groups are developed by the CRWMSM\&O. In addition, a waste package has been designed that accommodates a single DOE SNF canister in the center surrounded by five highlevel waste glass canisters". A cross-sectional view of a codisposal waste package is shown in Figure 1. DOE SNF in this configuration from each of the groups will be analyzed and data important to criticality control, such as fissile loading, enrichment, initial configuration of the basket and SNF, and neutron absorber loading in the canister, will be identified through the analyses. The disposal criticality analyses for these groups consider the supporting structural, thermal, and shielding analyses for the waste package.

The analyses developed by the three DOE sites currently storing DOE SNF or by the NSNPF for DOE SNF storage (10 CFR 72) and transportation (10 CFR 71) licenses with the NRC will be used to justify distribution of the $\sim 250$ fuel types to the nine representative fuel groups. The storage and transportation criticality analyses will specifically be used to demonstrate that the various fuels within a group are bounded by the analyses performed for the representative fuel. Documented justification will be required to apply these analyses to the disposal criticality analyses. Some analyses of degraded components will likely be necessary to demonstrate that some of the fuels are truly bounded by the degradation characteristics of the representative fuel in that group. : The criticality analyses for accumulations of fissile material outside the waste package are expected to be bounding for all fuel types and will require a minimal effort to demonstrate their applicability. If a fuel type is not bounded in any phase of the analyses then options such as canister de-rating (reducing the number of assemblies in a canister) may be employed. Re-grouping (shifting a fuel to a different group) may be justified based on analysis of the criticality-control criteria.

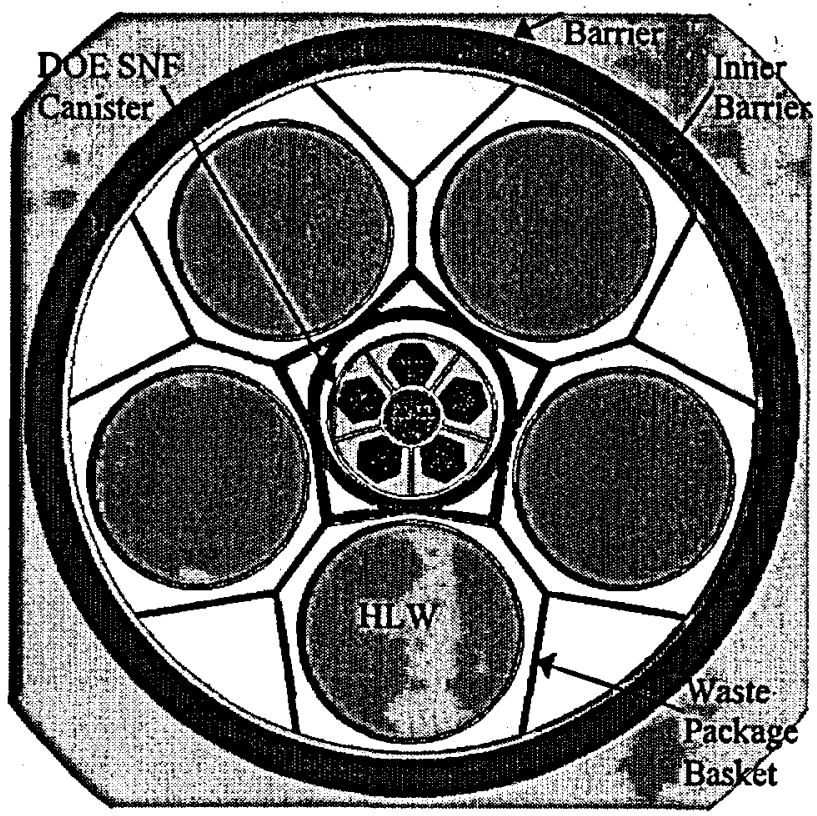

Figure 1. Cross-sectional View of a Codisposal Waste Package 


\section{DATA IDENTIFIED AS IMPORTANT TO CRITICALITY CONTROL}

Analyses have been performed or are currently in process for the first seven groups of DOE SNF. In general, the amount of DOE SNF allowed per canister is a function of the physical size and weight limitations of the canister. Insoluble neutron absorbers are required for most of the DOE SNF groups. To date, ${ }^{4,5}$, several items have been identified as important to criticality control. The DOE SNF canister shell is important to criticality control since it initially confines the fissile elements to a specific geometry and location within the waste package. The baskets developed for the representative fuel types are important since each basket initially confines the fissile elements to a specific geometry and location within the DOE SNF canister, and in many cases, provides the distribution mechanism for neutron absorbers. And finally, the performance and distribution of absorber is important to criticality control. The degraded configurations evaluated for each fuel type include varying degrees of degradation resulting in many different geometric configurations and fissile distributions. These degraded configurations also bound the other types of fuels in a group as long as the limits on mass and enrichment are not exceeded. The effects of relatively short-lived absorber (i.e., Pu-240) or fissile isotopes (i.e. Pu-241) are not important to criticality control because time (decay) effects are accounted for in the analyses and minimum times to breach are typically several thousand years.

\section{CONCLUSION}

The combination of grouping DOE SNF into the nine representative groups, utilizing analyses required for transportation and storage, and identifying the parameters driving the disposal criticality analyses results, are expected to do two things: maximize the coverage for disposal criticality control for geologic disposal of DOE SNF and reduce overall costs.

Consolidating or redefining groups may occur as the importance to criticality control is evaluated as the results for each fuel group are analyzed.
This work was performed by the CRWMS-M\&O and was sponsored by NSNFP under DOE-EM.

\section{REFERENCES}

1. DOE Spent Nuclear Fuel Grouping In Support of Criticality, DBE, TSPA-LA, DOE/SNF/REP-0046, Draft Revision 0, U.S. Department of Energy, Office of Environmental Management, Idaho National Engineering and Environmental Laboratory, Idaho Falls, Idaho, October 1999.

2. Disposal Criticality Analysis Methodology Topical Report, YMP/TR-004Q, U.S. Department Of Energy, Office Of Civilian Radioactive Waste Management, Las Vegas, Nevada, November 1998.

3. Preliminary Design Specification for Department of Energy Standardized Spent Nuclear Fuel Canisters, DOE/SNF/REP011, Revision 3, U.S. Department of Energy, Office of Environmental Management, Idaho National Engineering and Environmental Laboratory, Idaho Falls, Idaho, August 1999.

4. Evaluation of Codisposal Viability for MOX (FFTF) DOE-Owned Fuel, BBA00000001717-5705-00023 REV: 00, CRWMSM\&O, Las Vegas, Nevada, September 1999.

5. Evaluation of Codisposal Viability for U-ZrH (TRIGA) DOE-Owned Fuel, TDR-EDCNU-000001 REV 00, CRWMS-M\&O, Las Vegas, Nevada, January 2000.

\section{ACKNOWLEDGEMENTS}

